\title{
Analisa Optimasi Rute Transportasi Antar Jemput Siswa Menggunakan Model CGVRP dan Algoritma Dijkstra di SDIT Darus Sunnah
}

\author{
Koko Hermanto $^{1}$, Tita Dwi Ermayanti ${ }^{2}$ \\ ${ }^{1}$ Universitas Teknologi Sumbawa, koko.hermanto@uts.ac.id \\ ${ }^{2}$ Universitas Teknologi Sumbawa, Titadwie2397@gmail.com
}

\begin{abstract}
School transportation is one of the facilities provided by the school in the process of picking up students. In the process of picking up, taking the optimal route is needed to save costs and time. The purpose of this study is to develop a model School transportation routes using the Clustered Generalized Vehicle Routing Problem (CGVRP ) model and the Dijkstra algorithm to get a more optimal route from the route that has been used. Furthermore, comparing the real distance from the shuttle transportation routes with the distance from the results of this case study using the CGVRP model and the Dijkstra algorithm. From the research results obtained by using the CGVRP model and the Djikstra algorithm which is applied to the case study of shuttle students at Darus Sunnah SDIT We found that our result has shorter distance when compared to the distance of the usual route.. The total distance on the SDIT Darus Sunnah route is 2.746 .416 meters and costs Rp. 2.214.288 in a month. While the distance from the proposed route obtained 2.333.616 meters for at Rp. 1.881.478 in a month. Therefore the difference in the distance from the real route and the proposed route is 357.288 meters with a difference in cost of Rp. 332.820, - in a month.
\end{abstract}

Keywords: CGVRP method, Dijkstra Algorithm, shortest route, SDIT Darus Sunnah.

\begin{abstract}
Abstrak. Angkutan sekolah merupakan salah satu sarana yang disediakan oleh pihak sekolah dalam proses antar jemput peserta didik. Dalam proses antar jemput tersebut diperlukan rute yang optimal agar dapat menghemat biaya dan waktu. Tujuan penelitian ini untuk menyusun model rute transportasi antar jemput peserta didik dengan memodelkan permasalahan ke model Clustered Generalized Vehicle Routing Problem (CGVRP) dan Algoritma Dijkstra untuk mendapatkan rute yang lebih optimal dari rute yang selama ini digunakan. Selanjutnya membandingkan jarak rute real transportasi antar jemput dengan jarak rute hasil dari studi kasus ini dengan menggunakan model CGVRP dan Algoritma Dijkstra. Dari hasil penelitian diperoleh hasil dengan menggunakan model CGVRP dan Algoritma Djikstra yang diterapkan pada studi kasus antar jemput peserta didik di SDIT Darus Sunnah rute lebih pendek dibandingkan dengan jarak yang digunakan sebelumnya. Total jarak pada rute SDIT Darus Sunnah yaitu 2.746.416 meter dengan biaya Rp. 2.214.288 dalam sebulan. Sedangkan jarak pada rute usulan didapatkan 2.333.616 meter dengan biaya Rp.1.881.478 dalam sebulan. Sehingga didapatkan selisih jarak dari rute real dan rute usulan yaitu 357.288 meter dengan selisih biaya Rp. 332.820,dalam sebulan.
\end{abstract}

Kata Kunci: Metode CGVRP, Algoritma Dijkstra, rute terpendek, SDIT Darus Sunnah. 


\section{Pendahuluan}

Angkutan sekolah merupakan salah satu sarana yang dipersiapkan oleh beberapa sekolah yang diperuntukan mengantar jemput siswa-siswi sekolah demi kelancaran proses belajar mengajar. Sehingga dalam proses mengantar jemput siswa-siswi dari rumah ke sekolah ataupun sebaliknya sekolah ingin mempertimbangkan efisiensi waktu serta biaya. Dimana dalam hal ini biasanya pengendara selalu mengedepankan pengalaman pribadinya dalam pengantaran dan dirasa kurang efisien jika pengalaman tersebut ternyata bukan merupakan suatu pilihan terbaik yang bisa diambil saat menjalankan tugasnya. Untuk itu diperlukan ketepatan dalam pemilihan jalur atau rute dalam menentukan tujuantujuan yang akan dituju.

Masalah rute terpendek salah satu masalah sering ditemui dalam kehidupan sehari-hari, salah satunya pada bidang transportasi. Masalah menentukan rute terpendek menjadi masalah yang penting dikarenakan berkaitan dengan masalah meminimumkan biaya dan waktu yang dibutuhkan [1].

Pada penelitian ini, untuk menentukan rute terpendek pelayanan transportasi antar jemput SDIT menggunakan model CGVRP dan algoritma Dijkstra. Model CGVRP merupakan pengembangan dari metode Generalized Vehicle Routing Problem (GVRP) dimana setiap vertek-vertek yang menjadi tujuan dipartisi menjadi sejumlah rangkaian vertek-vertek yang disebut kluster kemudian ditentukan rute yang optimal dari depot ke sejumlah kluster yang telah ditetapkan yang meliputi tepat satu vertek dari setiap kluster, selanjutnya dimulai dari vertek tersebut akan dikunjungi setiap vertek yang dikunjungi tepat satu kali untuk menentukan rute optimal pada masing-masing kluster yang terbentuk serta kendaraan yang digunakan untuk pendistribusian lebih dari satu kendaraan yang identik dan kapasitasnya terbatas. Metode ini biasanya digunakan untuk meminimalisasikan biaya dan kendaraan dalam proses pendistribusian [1].

Algoritma Dijkstra merupakan sebuah algoritma digunakan untuk memecahkan masalah pencarian rute terpendek dengan menghitung bobot terkecil dari setiap vertek. Setiap bobot dari vertek yang belum terpilih akan dianalisis, kemudian dipilih vertek dengan bobot yang paling kecil. Apabila terdapat bobot yang lebih kecil melalui vertek tertentu, maka rute akan berubah mengikuti bobot yang lebih kecil tersebut, artinya rute lintasan akan berubah. Analisa algoritma Dijkstra akan berhenti saat vertek sudah terlewati semuanya [2].

Sehingga dari latar belakang tersebut metode ini membantu SDIT mengoptimal pelayanan transportasi antar jemput dengan perhitungan yang hampir pasti karena di SDIT sendiri untuk penetuan rutenya masih menggunakan perkiraan. Dengan pengoptimalan rute tersebut sekolah dapat meminimalkan biaya serta waktu kerja lebih efektif.

\section{Tinjauan pustaka}

\subsection{Teori Graph}

Graph $G$ didefinisikan sebagai pasangan himpunan $(V, A)$ ditulis dengan notasi $G=(V, A)$, dimana $V$ merupakan himpunan tidak-kosong dari vertek (simpul atau 
node) dan $A$ merupakan himpunan edge (sisi) yang menghubungkan sepasang vertek [3].

Graph Isomorfik merupakan Dua buah Graph yang sama tetapi secara geometri berbeda disebut Graph yang saling isomorfik. Dua buah Graph, $G_{1}$ dan $G_{2}$ dikatakan isomorfik jika terdapat korespondensi satu-satu antara vertek-vertek keduanya dan antara sisi-sisi keduaya sedemikian sehingga hubungan kebersisian tetap terjaga.

Lintasan Hamilton adalah lintasan melalui tiap vertek di dalam graph tepat satu kali. Bila lintasan itu kembalike vertek awal membentuk lintasan tertutup (sirkuit), maka lintasan tertutup dinamakan sirkuit Hamilton. Dengan kata lain, sirkuit Hamilton adalah sirkut yang melalui tiap vertek di dalam graph tepat satu kali, kecuali vertek awal (sekaligus vertek akhir) yang dikunjungi dua kali.

\subsection{Clustered Generalized Vehicle Routing Problem (CGVRP)}

Masalah generalized vehicle routing problem dinotasikan GVRP adalah masalah mencari rute terpendek yang direpresentasikan dengan sebuah graph berarah $G=(V, A)$ dengan $\mathrm{V}=\{0,1,2, \ldots, n\}$ sebagai himpunan vertek dan $A=$ $\{(i, j) \mid i, j \in V, i \neq j\}$ himpunan edge $C_{i j}$ bernilai nonnegative untuk setiap edge $(i, j) \in A$, himpunan vertek dibagi menjadi $k+1$ himpunan bagian tak kosong saling bebas, yang disebut dengan kluster $V_{0}, V_{1}, \ldots, V_{k}$ (i.e. $V=V_{0} \cup V_{1} \cup \ldots \cup$ $V_{k}$ dan $V_{l} \cap V_{p}=\varnothing$ untuk semua $l, p \in\{0,1, \ldots, k\}$ dan $l \neq p$ ) [4].

Varian dari GVRP didefinisikan sebagai masalah umum kluster rute kendaraan atau clustered generalized vehicle routing problem yang dinotasikan sebagai $C G V R P$, dimana semua vertek setiap kluster harus dikunjungi secara berurutan dalam rute kendaraan. Dengan demikian tujuan CGVRP adalah untuk menentukan koleksi biaya minimum dari $m$ tur kendaraan yang berawal dan berakhir di depot sehingga vertek dari tiap graph dikunjungi tepat satu kali dengan melakukan lintasan Halmiton pada tiap vertek, serta muatan masing-masing kendaraan tidak melebihi kapasitas $Q$ [4]. Ilustrasi $C G V R P$ dan solusi layak yang merupakan lanjutan dari masalah GVRP, yang dapat dilihat pada Gambar 1. 


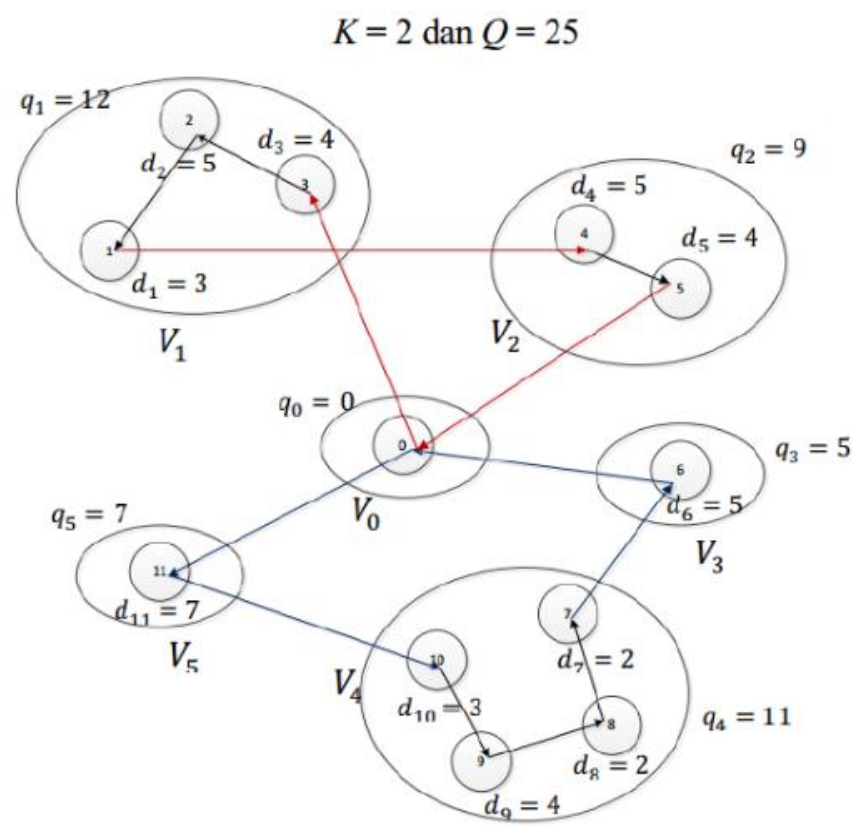

Gambar 1. Solusi layak CGVRP

Gambar 1 mejelaskan solusi layak CGVRP dari suatu masalah pendistribusian barang yang dilakukan oleh dua kendaraan yang identik dengan kapasitas kendaraan $Q=25$. Kendaraan pertama pendistribusian dimulai dari gudang $v_{0}$ menuju vertek $v_{3}$ dengan permintaan $d_{3}=4$ kemudian menuju vertek $v_{2}$ dengan permintaan $d_{2}=5$ selanjutnya menuju vertek $v_{1}$ dengan permintaan $d_{1}=3$ merupakan vertek-vertek yang ada di kluster $V_{1}$ dengan jumlah permintaan $d_{1}=$ $v_{4}+v_{2}+v_{4}=12$. Karena jumlah permintaan di kluster $V_{1}$ masih kurang dari kapasitas kendaraan maka kendaraan pertama ditugaskan menuju klaster $V_{2}$ yang memiliki jumlah permintaan $q_{2}=9$, diawali menuju vertek $v_{4}$ dengan permintaan $d_{4}=5$ kemudian menuju vertek $v_{5}$ dengan permintaan $d_{5}=4$. Karena total jumlah permintaan di $V_{1}$ dan $V_{2}$ adalah 21 maka tidak memungkinkan kendaraan pertama untuk mengunjungi kluster yang lain, selanjutnya kendaraan pertama tersebut kembali lagi ke gudang. Begitu juga dengan pendistribusian kendaraan kedua. Jadi rute optimal dari pendistribusian tersebut adalah jumlahan seluruh jarak edge-edge yang dilalui dua kendaraan pendistribusian tersebut [2].

\subsection{Algoritma Dijkstra}

Algoritma Dijkstra adalah algoritma pencarian graph yang memecahkan masalah jalur terpendek yang bersumber dari satu vertek untuk sebuah graph dengan bobot vertek tidak boleh negatif. Langkah prosedural algoritma dijkstra adalah sebagai berikut [5]:

1. Inisialisasi : $L=\{\} ; \mathrm{V}=\left\{v_{1}, v_{2}, v_{3} \ldots, v_{n}\right\}$

2. Untuk $\mathrm{i}=1,2, \ldots . ., \mathrm{n}$, Lakukan $\mathrm{D}(\mathrm{i})=W_{(1, i)}$

3. Selama $\mathrm{v}_{\mathrm{n}} \notin L\left(\mathrm{v}_{\mathrm{n}}\right.$ belum merupakan titik permanen) lakukan :

a. Pilih titik $v_{k} \in V-L$ (titik tidak permanen) dengan $D(k)$ terkecil. $L=L \cup\left\{v_{k}\right\}$ (jadikan $v_{k}$ menjadi titik permanen) 
b. Untuk setiap $v_{j} \in V-L$ lakukan :

Jika $\mathrm{D}(\mathrm{k})+W_{(k j)}<\mathrm{D}(\mathrm{j})$ makan ganti $\mathrm{D}(\mathrm{j})$ dengan $\mathrm{D}(\mathrm{k})+\mathrm{W}(\mathrm{k} . \mathrm{j})$

\section{Metodelogi Penelitian}

Analisis terhadap pengolahan data untuk mengoptimasikan rute tranportasi antar jemput siswa SDIT Darus Sunnah dengan menggunakan model Clustered Generalized Vehicle Routing Problem (CGVRP) dan algoritma Dijkstra, dilakukan langkah-langkah penelitian sebagai berikut :

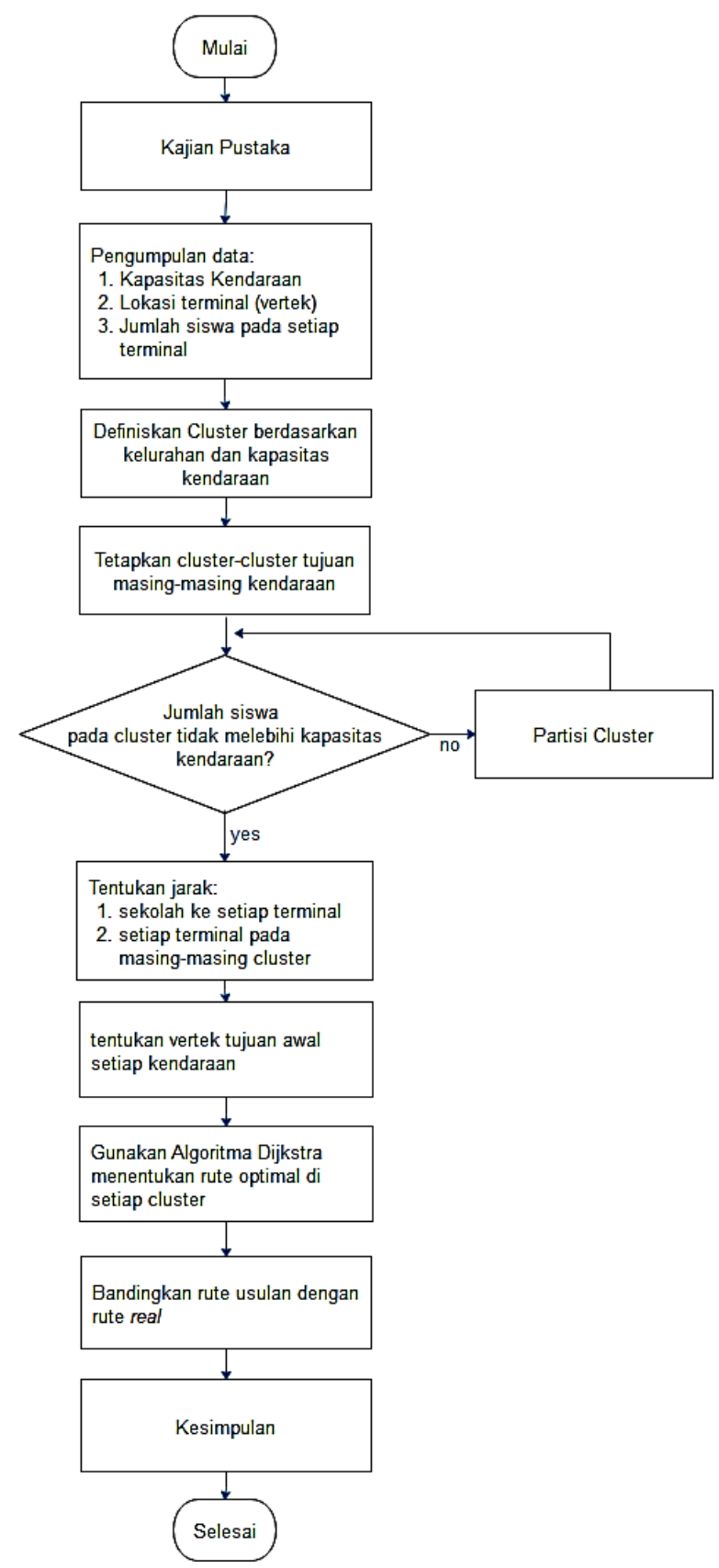

Gambar 2. Diagram alir penelitian 


\section{Hasil dan Diskusi}

Antar jemput peserta didik oleh SDIT Darus Sunnah kota Sumbawa Besar dari rumah ke sekolah dan sebaliknya menggunakan 3 kendaraan dengan total jarak tempuh mobil yaitu 57.217 meter per satu kali jalan, dengan total biaya Rp.46.131,- per satu kali jalan. Sehingga dalam satu bulan total jarak yang ditempuh yaitu 2.746.416 meter dengan total biaya yaitu Rp. 2.214.288,-Kendaraan tersebut memiliki kapasitas yang berbeda-beda yaitu 12 orang, 12 orang, dan 10 orang.

Dalam Pengukuran jarak untuk setiap terminal dapat diasumsikan bahwa kemacetan di rute antar jemput diabaikan sehingga jalan selalu dapat dilewati, dan jarak dari terminal ke-i ke terminal ke-j sama dengan jarak terminal ke-j ke terminal ke-i.Jarak setiap terminal dihitung dengan menggunakan google earth. Jarak antar terminal dapat dilihat sebagai berikut:

Tabel 1. Jarak antar Terminal

\begin{tabular}{|l|r|r|r|r|r|r|r|r|r|r|r|r|r|r|r|r|r|r|r|r|}
\hline \multicolumn{1}{|c|}{ Lokasi } & $\begin{array}{l}\text { Kode } \\
\text { lokasi }\end{array}$ & 0 & 1 & 2 & 3 & 4 & 5 & 6 & 7 & 8 & 9 & 10 & 11 & 12 & 13 & 14 & 15 & 16 & 17 & 18 \\
\hline Sekolah & 0 & 0 & & & & & & & & & & & & & & & & & \\
\hline Lempeh & 1 & 4361 & 0 & & & & & & & & & & & & & & & & \\
\hline Samapuin & 2 & 3395 & 2388 & 0 & & & & & & & & & & & & & & & & \\
\hline Panto Daeng & 3 & 2742 & 1409 & 1158 & 0 & & & & & & & & & & & & & & & \\
\hline Karang Goreng & 4 & 2794 & 1940 & 689 & 531 & 0 & & & & & & & & & & & & & & \\
\hline Brangbiji 1 & 5 & 6443 & 2068 & 3986 & 3491 & 4008 & 0 & & & & & & & & & & & & & \\
\hline Brangbiji 2 & 6 & 5608 & 1242 & 3160 & 2656 & 3182 & 835 & 0 & & & & & & & & & & & & \\
\hline Brangbiji 3 & 7 & 4649 & 288 & 2206 & 1697 & 2228 & 1780 & 954 & 0 & & & & & & & & & & & \\
\hline Labuhan 1 & 8 & 7120 & 2759 & 5147 & 4168 & 4699 & 1286 & 2121 & 3047 & 0 & & & & & & & & & & \\
\hline Labuhan 2 & 9 & 6880 & 2523 & 4911 & 3932 & 4463 & 1050 & 1885 & 2811 & 240 & 0 & & & & & & & & & \\
\hline Labuhan 4 & 10 & 7554 & 3193 & 5581 & 4602 & 5133 & 1720 & 2555 & 3481 & 434 & 665 & 0 & & & & & & & & \\
\hline Olatrarang & 11 & 6379 & 2814 & 5202 & 4223 & 4754 & 1746 & 2581 & 3507 & 840 & 696 & 1274 & 0 & & & & & & & \\
\hline Karang dima & 12 & 7231 & 4997 & 7385 & 6406 & 6937 & 3524 & 4359 & 5285 & 2238 & 2474 & 1804 & 3078 & 0 & & & & & & \\
\hline kebayan & 13 & 5212 & 851 & 2770 & 2260 & 2791 & 2467 & 1641 & 687 & 3610 & 3374 & 4044 & 3665 & 5848 & & 0 & & & & \\
\hline Seketeng 1 & 14 & 5275 & 4257 & 2212 & 3095 & 2564 & 5912 & 5077 & 4118 & 7016 & 6780 & 7450 & 7071 & 9254 & 2927 & 0 & & & \\
\hline seketeng 2 & 15 & 5065 & 4047 & 2147 & 2885 & 2354 & 5702 & 4867 & 3908 & 6806 & 6570 & 7240 & 6861 & 9044 & 3421 & 494 & 0 & & \\
\hline seketeng 3 & 16 & 5033 & 4015 & 2155 & 2853 & 2322 & 5670 & 4835 & 3876 & 6774 & 6538 & 7208 & 6829 & 9012 & 2645 & 704 & 1000 & 0 & \\
\hline bugis 1 & 17 & 3673 & 1317 & 1309 & 879 & 1410 & 2976 & 2150 & 1196 & 4076 & 3840 & 4510 & 4131 & 6314 & 1721 & 2605 & 2595 & 2563 & 0 & \\
\hline bugis 2 & 18 & 4386 & 1624 & 1478 & 1469 & 1644 & 3251 & 2425 & 1471 & 4383 & 4147 & 4817 & 4438 & 6621 & 2027 & 2266 & 2056 & 2024 & 590 & 0 \\
\hline
\end{tabular}

Sumber: Peneliti

Selanjutnya setiap terminal dikelompokan berdasarkan kelurahan masingmasing dengan tetap memperhatikan kapasitas kendaraan yaitu total siswa yang dijemput tidak melebihi kapasitas kendaraan bila melebihi kapasitas kendaraan maka dibentuk kelompok baru. jumlah siswa dan pengelompokan setiap terminal disajikan pada Tabel 2

Tabel 2. Pengelompokkan terminal

\begin{tabular}{clcccccc}
\hline No. & Kelurahan & $\begin{array}{c}\text { Kode } \\
\text { Kluster }\end{array}$ & $\begin{array}{c}\text { Tugas } \\
\text { Kendaraan }\end{array}$ & Terminal & $\begin{array}{c}\text { Kode } \\
\text { Vertek }\end{array}$ & $\begin{array}{c}\text { Total } \\
\text { siswa }\end{array}$ & $\begin{array}{c}\text { Jumlah } \\
\text { Siswa }\end{array}$ \\
\hline 1 & Lempeh & V2 & Kendaraan 1 & Lempeh & 1 & 1 & 1 \\
2 & Labuhan & V8 & & Labuhan 1 & 8 & 4 & 11 \\
& & & & Labuhan 2 & 9 & 2 & \\
& & & & Labuhan 3 & 11 & 2
\end{tabular}




\begin{tabular}{llcclccc}
\hline No. & Kelurahan & $\begin{array}{c}\text { Kode } \\
\text { Kluster }\end{array}$ & $\begin{array}{c}\text { Tugas } \\
\text { Kendaraan }\end{array}$ & Terminal & $\begin{array}{c}\text { Kode } \\
\text { Vertek }\end{array}$ & $\begin{array}{c}\text { Total } \\
\text { siswa }\end{array}$ & $\begin{array}{c}\text { Jumlah } \\
\text { Siswa }\end{array}$ \\
\hline & & & & Labuhan 4 & 10 & 3 & \\
\hline 3 & Seketeng & V1 & Kendaraan 2 & Seketeng 1 & 14 & 1 & 4 \\
& & & & Seketeng 2 & 15 & 2 & \\
& & & & Seketeng 3 & 16 & 1 & \\
4 & Kebayan & V3 & & Kebayan & 13 & 1 & 1 \\
5 & Samapuin & V4 & & Samapuin & 2 & 2 & 2 \\
6 & Brang Bara & V5 & & Pantodaeng & 3 & 2 & 5 \\
& & & & Karang Goreng & 4 & 3 & \\
\hline 7 & Bugis & V6 & Kendaraan 3 & Bugis 1 & 17 & 1 & 2 \\
& & & & Bugis 2 & 18 & 1 & \\
8 & Brangbiji & V7 & & Brangbiji 1 & 5 & 2 & 5 \\
& & & & Brangbiji 2 & 6 & 1 & \\
& & & & Brangbiji 3 & 7 & 2 & \\
9 & Karang dima & V9 & & karang dima & 12 & 3 & 3 \\
\hline
\end{tabular}

Sumber: Peneliti

Berdasarkan Tabel 2 dapat diilustrasikan lokasi dan pengelompokan terminal ke model GVRP seperti Gambar 1 berikut.

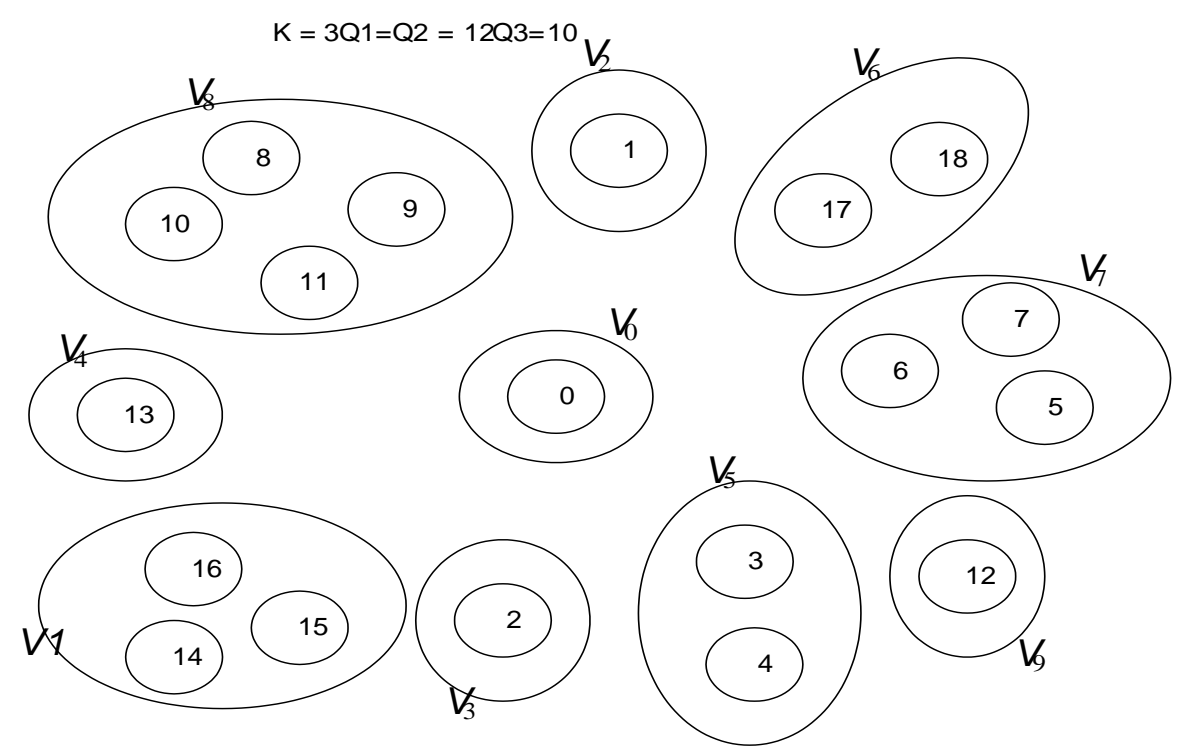

Gambar 1. pengelompokan terminal

Pada pembahasan selanjutnya akan dijelaskan contoh analisa perhitungan dengan menggunakan algoritma Dijkstra pada kendaraan 1 yang ditugaskan pada kluster $V 2$ dan V8. 
Kendaraan ke-1 ditugaskan mengunjungi dua Kluster yaitu Kluster 2 dan Kluster 8. Ditentukan tujuan awal dari kendaraan 1 yaitu vertek yang paling pendek dari kedua Kluster tersebut, yang dapat dilihat pada matriks dibawah ini

$$
\begin{aligned}
& \begin{array}{llllll}
v_{0} & v_{1} & v_{8} & v_{9} & v_{10} & v_{11}
\end{array} \\
& \mathrm{G}=v_{0} \quad\left[\begin{array}{llllll}
\infty & 4361 & 7120 & 6880 & 7554 & 6379
\end{array}\right]
\end{aligned}
$$

Dari matriks diatas tujuan awal kendaraan 1 yaitu $v_{1}$ yang berada di Kluster 2. Selanjutnya akan ditentukan tujuan dari kendaraan 1 ke Kluster 8 (karena Kluster 2 hanya memiliki satu vertek) maka tujuan vertek utama di Kluster 8 dapat ditentukan sebagai berikut:

$$
\begin{aligned}
& \begin{array}{lllll}
v_{1} & v_{8} & v_{9} & v_{10} & v_{11}
\end{array} \\
& \mathrm{G}=v_{1}\left[\begin{array}{lllll}
\infty & 2756 & 2523 & 3193 & 2814
\end{array}\right]
\end{aligned}
$$

Dari matriks di atas maka tujuan selanjutnya adalah $v_{9}$. Selanjutnya dengan menggunakan metode Algoritma Dijkstra akan ditentukan rute pada Kluster 8:

$$
\mathrm{G}=\begin{array}{ccccc} 
& v_{8} & v_{9} & v_{10} & v_{11} \\
v_{8} & v_{9} \\
v_{10} \\
v_{11}
\end{array}\left[\begin{array}{ccccc}
\infty & 240 & 434 & 840 \\
240 & \infty & 665 & 696 \\
434 & 665 & \infty & 1274 \\
840 & 696 & 1274 & \infty
\end{array}\right]
$$

$\mathrm{I}=0$

Mula-mula $\mathrm{L}=\left\{v_{9}\right\}$ dan $v=\left\{v_{8},, v_{10}, v_{11}\right\}$

$\mathrm{D}(8)=\mathrm{G}(9,8)=240$

\begin{tabular}{|c|c|c|c|c|c|}
\hline I & $\mathrm{D}(9)$ & $\mathrm{D}(\mathbf{8})$ & $\mathrm{D}(\mathbf{1 0})$ & $\mathrm{D}(\mathbf{1 1})$ & $\mathbf{L}$ \\
\hline $\mathbf{0}$ & 0 & $\infty$ & $\infty$ & $\infty$ & $\left\{v_{9}\right\}$ \\
\hline $\mathbf{1}$ & - & $\begin{array}{l}\operatorname{Min}\{\infty \\
0+240\} \\
=240\}\end{array}$ & $\begin{array}{l}\operatorname{Min}\{\infty \\
0+665\}=665\end{array}$ & $\begin{array}{l}\operatorname{Min}\{\infty \\
0+696\}=696\end{array}$ & $\left\{v_{9}, v_{8}\right\}$ \\
\hline 2 & - & & $\begin{array}{l}\operatorname{Min}\{665 \\
240+434\} \\
=665\end{array}$ & $\begin{array}{l}\operatorname{Min}\{696 \\
240+840\} \\
=696\end{array}$ & $\left\{v_{9}, v_{8}, v_{10}\right\}$ \\
\hline 3 & & & & $\begin{array}{l}\operatorname{Min}\{696 \\
665+1274\} \\
=696\end{array}$ & $\begin{array}{c}\left\{, v_{9}, v_{8}, v_{10}\right. \\
\left.v_{11}\right\}\end{array}$ \\
\hline
\end{tabular}

$\mathrm{D}(10)=\mathrm{G}(9,10)=665$

$\mathrm{D}(11)=\mathrm{G}(9,11)=696$

Pada iterasi pertama, $\mathrm{D}(9)=0$ dan diambil sebagai titik permanen pertama $\mathrm{L}=\left\{v_{9}\right\}$. Iterasi selengkapnya tampak pada tabel 3 .

Tabel 3 Iterasi dari Kluster 8 
Dengan cara yang sama dapat ditentukan rute antar jemput untuk kendaraankendaraan yang lainnya, sehingga hasil yang didapatkan dari hasil analisa dapat dimodelkan dalam graph model $C G V R P$ sebagai penyelesaian layak disajikan pada gambar 2.

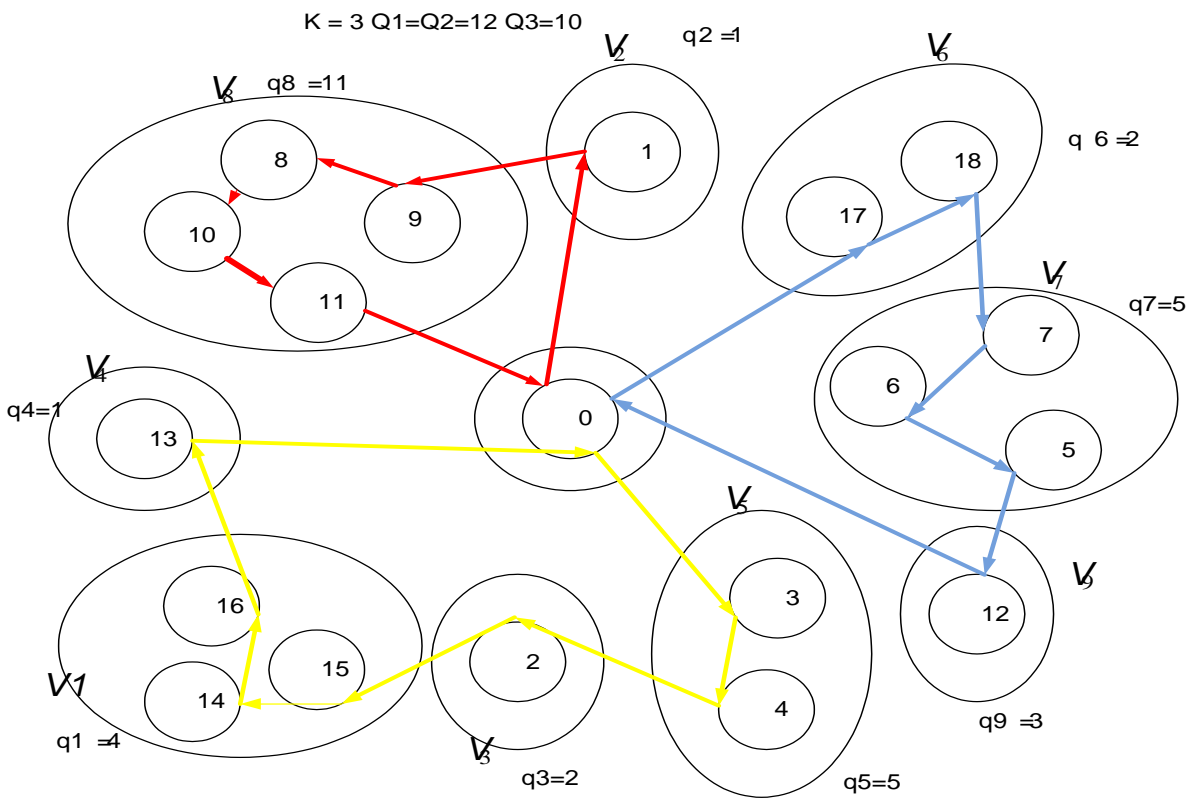

Gambar 2. Rute antar jemput SDIT Darus Sunnah model CGVRP

Dari Gambar 2 dapat dilihat solusi usulan rute antar jemput peserta didik di SDIT Darus Sunnah. Diperoleh total rute sepanjang 48.617meter per satu kali jalan. Bahan bakar yang digunakan oleh mobil pengantaraan adalah bensin dengan harga perliternya Rp. 6.450,- dan satu liter dapat menempuh jarak 8.000 meter, sehingga biaya bahan bakar untuk pengantaran siswa adalah Rp 39.197per satu kali jalan. Dimana dalam sehari terdapat 2 kali perjalanan sehingga sehari menempuh jarak $2 \times 48.617$ meter=97.234 meter maka biaya yang dikeluarkan dalam sehari yaitu $2 \times$ Rp.39.197=Rp.78.395,-. Dimana Sekolah aktif selama 24 hari dalam satu bulan maka total jarak yang ditempuh yaitu jarak $24 \times 97.234$ meter $=2.333 .616$ meter dan biaya yang dikeluarkan sebesar $24 \times$ Rp.78.395 = Rp.1.881.478,--

\section{Kesimpulan}

Proses antar jemput yang dilakukan dengan metode CGVRP dan Algoritma Dijkstra menghasilkan rute yang mampu mengoptimalkan jarak dari sekolah ke terminal-terminal yang telah ditentukan. Metode CGVRP menggunakan Algoritma Dijkstra yang diterapkan pada studi kasus antar jemput peserta didik di SDIT Darus Sunnah dan SDIT Samawa Cendekia lebih hemat dibandingkan dengan jarak yang digunakan sebelumnya. Total jarak pada rute SDIT Darus Sunnah yaitu 2.746.416 meter dengan biaya Rp. 2.214.288 dalam sebulan. Sedangkan jarak pada rute usulan didapatkan 2.333.616 meter dengan biaya Rp.1.881.478 dalam sebulan. Penghematan jarak tempuh untuk SDIT Darus 
Sunnah sebesar 357.288 meter dalam satu bulan sehingga diperoleh hemat biaya bahan bakar distribusi sebesar Rp. 332.820,- dalam satu bulan.

\section{Ucapan Terma kasih}

Tim peneliti mengucapkan terima kasih kepada kepala sekolah serta pihakpihak sekolah SDIT Darus Sunnah kota Sumbawa Besar yang telah terlibat memberikan informasi-informasi yang dibutuhkan pada penelitian ini.

\section{Daftar Pustaka}

[1] Hermanto, K., \& Ruskartina, E. 2017. Usulan Rute Optimal Distribusi Sampah Shift I Kota Sumbawa Besar Menggunakan Metode GVRP. Eigen Mathematics Journa. 1(2):7-12.

[2] Hermanto, K., \& Ruskartina, E. 2017. Optimasi Rute Truk Pengangkutan Sampah Di Kota Sumbawa Besar Shift II Menggunakan GVRP. Jurnal UJMC.4(2):15-23.

[3] Munir, Rinaldi. 2005. "Matematika Diskrit". Bandung: Informatika Bandung.

[4] Petrica, POP.2011.A New Efficient Transformation Of The Generalized Vehicle Routing Problem Into The Classical Vehicle Routing Problem".Jurnal Riset Operasi.North University of Baia Mare.Romania.

[5] Jek Siang, Jong.2014."Riset Operasi Pada Pendekatan Algoritmis". Yogyakarta: Penerbit Andi. 